\title{
Consumer Behaviour at the Generic Level: Theoretical Perspectives ${ }^{1}$
}

\author{
Rahmat Hidayat ${ }^{2}$ \\ Faculty of Psychology Universitas Gadjah Mada
}

\section{Introduction}

Suppose you had unexpectedly received some money, for instance a gift or a lottery prize. What would you like to do with the money? Why the action you chose to do is of much importance to you? What would you like to achieve by that action? This is a simple illustration of the generic level of consumer decision making, henceforth the generic level. It is important to note that neither money nor unexpectedness defines the generic level. Although there are plenty of examples of receiving a windfall, gifts and lottery prizes being two of them, the generic level also concerns situations when expectations rule. For example, people may expect to receive a bumper bonus, an extra profit, a tax return, gain excessive money from a previous budget, or even to inherit some valuable assets from their beloved parents. To a certain degree, people in such situations must ponder of the different ways to utilize the money. The defining features of the generic level concern the mental processes of decision making in which an individual is trying to allocate a consumer resource into different categories of activities (Van Veldhoven \& Groenland, 1993).

\footnotetext{
${ }^{1}$ Tulisan ini merupakan bagian dari disertasi yang diajukan penulis untuk mendapatkan gelar Ph.D. dari Universitas Tilburg, Belanda.

${ }^{2}$ Korespondensi mengenai artikel ini dapat melalui: r.hidayat@ugm.ac.id
}

Consumer resources also concern time. The generic level of decision making also takes place when one is having a free time, either expectedly or unexpectedly. Examples include situations such as being stranded at a strange place due to travel chaos, cancellation of a planned appointment, or free time due to earlier accomplishment of a job. One is likely to think over alternative ways of using the time, such as reading a book, window shopping, listening to favourite music, working with a notebook, or having a chat over the internet. A particularly common situation is retirement, both voluntary and involuntary retirement due to work lay off (Van Solinge, 2006). One may opt an extended summer holiday, learn a new skill, or take on a new life project such as writing a book. Such choices can be characterized in terms of utilitarian and hedonic or experiential values (e.g., Dhar \& Wertenbroch, 2000).

It may sound strange, but having social power appears to incite problems of sorts, in the generic level. A newly installed politician at a public office knows this well as he or she must decide on different ways of using public assets. Being the leader of a peer group, be it at a kindergarten or a university student club, confronts one with similar kinds of problems. Parents certainly have constant problems allocating time for different sorts of children activities; whether more tennis or music, play time, or taking extra 
lessons. A particular interest of the generic level concerns the immediate versus longterm consequences of the alternative activities.

Life transitions often force people to make some generic level decisions. Take divorce as an example. Direct consequences of a divorce settlement may include changes in the amount of income, place of residence, social identity, and daily chores (Poortman, 2002). A divorce settlement often requires the divorcee to redefine life, such as whether to get married again or whether to venture a work or career (Hetherington \& Kelly, 2002), and decide what lifestyle or standard of living are acceptable, and even friendship and personal network to maintain (Terhell, 2003). Decision making at a life transition represents a strategic type of the generic level of consumer decision making. It involves choices between different types of life themes and values (e.g., Huffman, Ratneshwar \& Mick, 2000).

The aforementioned situations occur at the individual level. But, life transition may occur at a mass-scale, such as in the aftermath of a major natural disaster. Large scale disasters, such as the $26^{\text {th }}$ December 2004 tsunami, left the survivors unwillingly to redefine their life. Imagine the thoughts emerging within one who had just lost his wife, children and most of his family members, house and almost everything he/she had ever owned, as well as the place and tools to work. A man who I happened to encounter in Aceh, Indonesia, 11 days after the tsunami simply stated, "I don't know what I am going to do with my life." This expresses a sense of loss for one's life goals, experienced by many of the survivors, synonymous to a loss in one's meaning of life (Carballo, Heal \& Horbaty, 2006) at a mass scale.
Goals at the most general level can be equated to a generic goal. It concerns major categories of desired end states of one's life, and may thus constitute the meaning of life itself.

In short, the generic level concerns all types of consumer resources, namely money, effort, social power, and time, including the live-time of the consumer itself. It occurs at the individual as well as at the societal levels. The mental processes are articulated when an individual is deliberating choices of activities related to a resource. The objective of the decision making is to optimize the utility or benefit for the short- and long-term interests of the consumer. The higher the value of the resources concerned, the higher the involvement in the processes of decision making. At a certain level, these processes may require one to look inward deeply, to search one's soul, to examine faiths and fundamental values, and to contemplate what life means to the consumer.

How the generic level relates to other aspects of consumer behaviour?

A generic level of consumer behaviour can be distinguished from the other levels of consumer decision-making, namely specific allocation and modal allocation levels of consumer behaviour (Antonides \& Van Raaij, 1998; Van Veldhoven \& Groenland, 1993). The specific allocation level of consumer behaviour concerns problems of choice between brands and brand types of a product or service. The modal allocation level takes place when decisions within the product domain are concerned. For example, consumers may consider whether to save a windfall income in a certificate of deposit or to invest in a venture capital. At the generic allocation level, decisions between major categories of budgets, namely saving and 
spending, are the primary concerns for the consumer.

The specific, modal, and generic level all contributes to the welfare of the individual. In particular, the generic level of consumer decision making has strategic consequences. According to Thaler (1985), saving and spending represents the most important types of economic behaviour of individuals and households. Considering that decisions regarding saving and spending are taken at the generic level, many aspects of the consumers' life are highly influenced by the processes of decision making at the generic level. For example, financial security or vulnerability of individual consumers and households are likely to be a consequence of past decision making processes at the generic level. This implies that high quality generic level decision making will significantly contribute to the well-being of individual consumers and households. The following are two cases that illustrate the strategic importance of the generic level:

"Michael Carroll won $£ 9.7$ million in the National Lottery in 2002. Immediately he bought four homes, a holiday villa in Spain, two convertible BMWs, two Mercedes-Benz cars, a stake in a beloved football club, spent "untold thousands" on alcohol and drugs, wears a very large amount of gold jewellery. Eighteen months after winning the lottery, all of the fortune had been spent on this extravagant life, and now he is nearly broke" (Wikipedia)

“Brad Duke, 34, pocketed a lump sum of \$85 million after winning a \$220 million Powerball jackpot in 2005. He spent the first month of his new life assembling a team of financial advisors. The portfolio he has built: $\$ 45$ million in municipal bonds, \$35 million on oil and gas stocks and real estate, $\$ 18,000$ repayment on student loan, $\$ 125,000$ paying off mortgage. He also set $\$ 1,3$ million family foundation. He spent $\$ 63,000$ on a trip to Tahiti with 17 friends, $\$ 12,000$ annual gift to each of his family members, and $\$ 14,500$ on a hobby car. Eighteen months after wining his fortune, he is on course of his goal: to become a billionaire in 10 years" (CNN Money).

Scientific examination to the lottery winning phenomena are reported in Nissle and Bschor (2002), and Gardner and Oswald (2001).

Not only is this an important problem, the generic level of consumer behaviour is also a common problem. For some time now, empirical studies have revealed individual differences in the propensity to save (Wärneryd, 1999). Whereas some people routinely put aside a certain portion of their income, others fail to do so, on a regular basis, and the rest is never saving. Even among those who regularly save, many are doing so for amounts that are too small or in times that are too late. A survey shows that when people get older, they usually regret their lower savings: 60 per cent wish they had saved more when they were younger (BMRB International, 1994). In retrospect, older people often regretted their late start on pension savings (Prudential UK, 1996). As evident in the survey, $42 \%$ of the respondents agreed to the statement: "I wish I had considered my pension arrangement earlier." This is at odds with the common belief in many cultural settings that saving is considered a virtue (Lea, Tarpy, \& Webley, 1999), as well as the answers of most people that they would like to save their money (Wärneryd, 1999). However, this observation fits with an assertion 
made by Katona (1975, p. 235), that is, "plans to save often represent good intentions that are not carried out at a later date."

Saving is not only a problem at the individual or household level. At the macroeconomic level, low saving rates have become problems in many developed countries. For example, the Financial Research Survey (1996) reports that 26 percent of the UK labour force has no saving or financial investment at all. Of it, 22 and 21 percent are among those aged 45-54 and 55-64 years, respectively. Thirty three per cent of the former group and $26 \%$ of the latter have less than $£ 500$ in their current saving and investment accounts. Furthermore, 40 percent of working adults inadequately contribute to their pension. Should these current trends continue, it will pay out less than 40 per cent of their final salary.

Under-saving represents another side of consumer problems, namely over spending. It has become both individual and societal problems (e.g., Schor, 2000). Various explanations have been offered. Among others, the urge to conspicuous consumption, an explanation offered by Thorsten Veblen dated back to the late 19th century (Veblen, 1899/2000). Another explanation is concerned with the desire to keep up with the Jones's (Duesenberry, 1949). With the advent of the new era of consumerism, mediated by the high penetration of television, it causes the upscaling of consumer aspirations, spending, and norms (e.g., Schor, 2000).

Both facets of the problem may originate at the generic level of consumer behaviour. That is, the failure to identify goals that include needs and wants at present time and in the future, and the failure to budget current and future income accordingly. Another problem is concerned with the failure of self-control with regard to prior budget commitment (Shefrin \& Thaler, 1988). Self-control is often discussed outside the area of the generic level of consumer behaviour. However, there is no point in self-control if there is no prior budget commitment, which is conceptually determined at the generic level. Moreover, self-control may increase or decrease with the clarity of budget commitment (Baumeister, Heatherton, \& Tice, 1994).

Toward this end, studying the generic level of consumer behaviour is relevant to economic psychology, government policy, and everyday practice. For the economic psychologist, the study may advance knowledge of consumer behaviour. For consumers, it is a way to understand their behaviour as well as a means to improve the direction towards a more goal-directed behaviour. To policy makers, it may increase the accuracy of welfare policy and planning. This is important in the context of problems regarding household saving in many developed economies. To marketers, it is relevant for marketing products in the strategic domain of consumer behaviour.

\section{Theoretical approaches to generic level}

The generic level of consumer behaviour involves saving and spending. In terms of behavioural and psychological processes, a generic level involves decision-making processes along with the sub-processes such as information search, deliberation, and judgment (Baron, 2000). Along the processes, different facets of the self of the decision maker are involved. Hence, three theoretical approaches are relevant to the analysis of the generic level of consumer behaviour, namely economic, behavioural, and psychological approaches. Differences between these approaches 
have been a subject of discussion (e.g., Hogarth \& Reder, 1986; Earl, 1990; Lopes, 1994; Lunt, 1996; Van Raaij, 1999; Wärneryd, 1999). Perspectives of each of the approaches will be summarized in the following three sections.

\section{Economic approach}

A generic allocation problem is at the heart of the economic discipline. It is defined as a study regarding how an economy or individual chooses to allocate scarce resources to different uses and over time (Samuelson \& Nordhaus, 1992). The objective of an economic study is to make predictions and to provide recommendations. The fundamental assumption is that economic agents (individuals, firms, or nations) are rational and act rationally. It means they attempt to maximize their utilities or profits from they way they allocate their resources. Furthermore, interactions between rational agents with rational expectations create a market that enforces agents to behave rationally. Market forces will eliminate irrational agents through processes of profit taking by rational agents. Thus, the theory assumes perfect competition on the side of the market. These two assumptions are obviously very strong and it is unlikely that they withstand empirical examination. Nevertheless, they may serve useful analytical objectives (Kirzner, 1997). It does not matter whether the assumption does not correspond to reality, as long as the theory provides useful predictions. Friedman (1953) suggests an eloquent analogy of economic theory to an expert billiard player. In his words:

"It seems not at all unreasonable that excellent predictions would be yielded by the hypothesis that the billiard player made his shots as if he knew the complicated mathematical for- mulas that would give the optimum directions of travel, could estimate accurately by eye the angles, etc., .... could make lightning calculations from the formulas, and could then make the balls travel in the direction indicated by the formulas." (p. 21).

In reality it is obvious that very few expert billiard players, if any at all, are well versed with mathematics and physics to match their expertise. It is not necessary to master mathematics and physics in order to become an expert billiard player, as it is not necessarily true that every economic agent is indeed perfectly rational and every market is perfectly competitive. Rationality and market competition are approximations for the way economic agents are interacting and market mechanisms are developing.

The rational behaviour of the economic agent is the cornerstone of microeconomic theory. A rational agent has stable preferences. It means, among others, that preferences are relatively stable over time, and that emotional and contextual factors do not influence preferences. Another assumption is that immediate consumption of a resource is preferred to delayed consumption or saving. However, it is also accepted that the satisfaction an agent obtains from consumption at one time is dependent on consumption at the previous time. The law of diminishing marginal utility of consumption states that the satisfaction one obtains from every additional unit is diminishing. The second glass of coke is less satisfying than the first, and the third is less than the second glass. Thus, the law dictates that after certain level of consumption is reached, a further unit of consumption cannot provide significant satisfaction. This principle can be applied to explain generic allocation problems of consumer behaviour. 
Consumer resources will be saved when consumption out of it has reached its optimum utility.

The principle may be extended to include inter-temporal concerns of consumption. Maximum utility can be obtained by distributing consumption of a resource over a period of time. A unit of consumption gives higher level of satisfaction after a certain period of time, as compared to the consumption of the same unit right after previous consumption. Thus, a rational consumer is assumed to weigh the marginal utility derived from consumption now to that of the future. Saving is a mechanism to smoothen consumption over time, so as to maximize utility over the period. Important theories in applying this principle are the life-cycle theory (Modigliani \& Brumberg, 1954; Modigliani, 1986) and permanent income theory (Friedman, 1957). The gist of these theories is illustrated eloquently in Thaler (1994):

"How much should ... a person consume in a given year? The answer is this: in any year, compute the present value of financial wealth, including current income, net assets, and the expected value of future income; figure out the level annuity that could be purchased with that money; then consume the amount that would be received from such an annuity" (pp. 107-108).

From this brief overview, it can be concluded that economic theories focus on prediction and prescription. The theoretical approach is based on assumption of rationality of the economic agent. Although the assumption has been defended as acquiring descriptive power, it is more appropriately conceived as a normative assumption (e.g., Thaler, 1980). A highly relevant assumption to the generic allo- cation level of consumer behaviour is that consumption is preferred to saving. Thus, saving is what is left over from consumption (Lea, Tarpy, \& Webley, 1987). This definition signifies the residual nature of saving, against which Katona (1975) shows other types of saving, namely discretionary and contractual savings. Moreover, extensive empirical studies have consistently identified several saving motives, namely precautionary, transactional, speculative, retirement, and inter vivo and bequest saving motives (Katona, 1975; Nyhus, 2002). Within the policy domain, the primary saving models (e.g., the lifecycle model, the precautionary savings model, the bequest motive model) have not been successful in explaining why so many elderly reach retirement with little or no savings (Gustman \& Juster, 1996; Poterba, 1996).

\section{Behavioural approach}

Alternative approaches to mainstream economic theories are offered in the behavioural theories of consumer choice. An enriched model was developed by Shefrin and Thaler (1988) and was called the Behavioural Life Cycle Hypothesis (BLCH). The model includes the notion of self-control (Thaler \& Shefrin, 1981), mental accounting (Thaler, 1980, 1985, 1999), and framing effects (Tversky \& Kahneman, 1981, 1986; Kahneman \& Tversky, 1984). Contrary to mainstream economic theory, behavioural economics assumes that self-control is the fundamental problem of an economic agent (Thaler, 2000; Jolls, Sunstein, \& Thaler, 1998; Barberis \& Thaler, 2003). A strategy for overcoming self-control is to adopt mental accounting, that is, a set of cognitive operations used by individual consumers and households to organize, evaluate, and keep track of financial expend- 
itures (Thaler, 1999). An important mental accounting practice in financial behaviour is that income and wealth are organized in separate mental accounts that implies differential marginal propensity to consume different sizes of income, namely current income account, current asset accounts, and future income account (Shefrin \& Thaler, 1988). The behavioural approach to consumer behaviour assumes fundamental problems in terms of bounded rationality, bounded willpower, and bounded self-control (Mulainathan \& Thaler, 2000; Thaler, 2000; Jolls, Sunstein, \& Thaler, 1998).

In mental accounting, expenditures are grouped into categories (housing, food, clothing, etc.). Similarly, wealth is assigned in one of the three mental accounts, namely current income account, current asset account, and future income account. Expenditures are financed from money drawn from corresponding accounts. For example, money deducted from current income account is for spending on food and entertainment, whereas home improvement is financed from current asset accounts. Each mental account is associated with a different propensity to save and to spend. Specifically, the current income is almost completely spent whereas future income is not at all consumed. The marginal propensity to consume (MPC) current assets is in between the MPC of current income and the MPC of future income.

Mental accounting also implies that money is not fungible. That is, money in a mental account is not a perfect substitute for money in another mental account (Thaler, 1999). Henderson and Peterson (1992) offer a cognitive psychological interpretation of mental accounting. They argue that the framing processes underlying mental accounting are the same as the processes described in categorization, schema, and script theories. Thus they suggest the use of existing theories when attempting to explain mental accounting processes.

Another important feature of the BLCH concerns modelling consumer efforts for establishing self-control. The model is based on the assumption of two competing functions in the consumer, namely the planner and the doer (Thaler \& Shefrin, 1981). The planner is always trying to secure long-term interest of the consumer, whilst the doer is pathologically myopic. The latter tempts consumers to spend income as soon as possible. Exercising control over the power of the doer is assumed to require willpower effort, which implies negative utility for the consumer. Mental accounting is viewed as a way for exercising self-control. In addition, pre-commitment devices such as a contractual obligation to save, similar as the notion of contractual saving (Katona, 1975), are viewed as devices to help exercise self-control.

The BLCH claims to be able to predict consumer behaviour regarding pensions and saving, and the effect of transitory income (Shefrin \& Thaler, 1998). In comparison to standard economic theory, BLCH claims superiority in explaining two anomalies regarding consumption. The first anomaly concerns the robust observation that consumption is excessively sensitive to income. The second anomaly concerns the non-fungibility of various forms of wealth (Thaler, 1994), as described briefly in the preceding paragraph. $\mathrm{BLCH}$ commands strong implication for policies. For example, changes from the procedure of opt-in to opt-out in the pension scheme offered to the employees, as recommended by $\mathrm{BLCH}$, have increased participations in pension plan, a claim 
having already been substantiated (Thaler \& Bernartzi, 2004). Subsequently, recommendations based on BLCH have been applied to national pension policies in several developed countries, such as the USA, the UK, and New Zealand (The Economist, 2005).

Although the behavioural approach to consumer behaviour adopts more realistic assumptions regarding human behaviour, the focus of the research remains the same as mainstream economics, namely prediction. Contrary to the mainstream theories, $\mathrm{BLCH}$ reflects the limitations of human capacities, particularly with regards to problems of self-control, and are thus substantially closer to capturing the reality in consumer behaviour. Nevertheless, it is taken for granted that individuals assign their income and wealth into a number of budgets. Questions such as how budget categories are formed, for what purpose, where the purposes come from, and how the source of a purpose may affect the ability to self-control, are not addressed in BLCH. For this, we may say that the theory has missed another quality of human being, namely the capacity for selfregulation (Bandura, 2001). Further Bandura (2001) argues that the unparallel success of human beings in evolutionary history did not materialize without the capacity for self-regulation of human thought and action. It is plausible to assume that consumer behaviour is selfregulated, especially at the generic level when a consumer is considering ways of utilizing resources at his or her disposal.

\section{Psychological approach}

Psychological research is concerned with describing the behaviour and the processes underlying the behaviour. Theories are developed on the basis of empirical observations through various experi- mental and survey methods. The theories accommodate several factors, namely internal factors (i.e., personality, motivation, attitude), psychological processes (i.e., cognitive and affective processes), and external factors (i.e., stimuli, context) in the explanation of the behaviour.

One of major theoretical approach in psychology is the social cognitive theory. The most complete version of the theory was introduced by Bandura (1986). Among others, the theory assumes the capacity of human agency. It reflects the essence of being human as the capacity to exercise control over the nature and quality of one's life. These capacities are achieved through functional capabilities of human agency, namely intentionality, forethought, self-reactiveness, and self-reflectiveness. These capacities enable human being to self-regulate their behaviour.

According to Vohs and Baumeister (2004), self-regulation is the capacity of individuals to guide themselves, in any way possible, toward important goal states. It refers to the executive and controlling aspects of the self. Self-regulatory mechanisms determine how an individual actively attempts to construct and modify his or her own thoughts, feelings, and behaviour and also to influence and change the environment (Kunda, 1999). It refers to purposive behaviours in which the individual performs self-corrective adjustments when necessary, in order to stay on track for whatever purpose is under pursuit, for which the corrective adjustments originate from within the system (Carver, 2003). Thus a self-regulatory mechanism reflects regulation $b y$ the self, not just regulation of the self (Vohs \& Baumeister, 2004), and reflects the proactive qualities of mind (Caprara \& Cervone, 2000), or a voluntary action management (Karoly, 1993). It works through conscious 
and unconscious processes. Thus, selfregulation provides a framework on how the self is put together in behaviour in many contexts of human life.

Many theories of self-regulation have been proposed. There are theories that specifically address the basic processes of self-regulation (e.g., Carver \& Scheier, 1981; Mischel \& Ayduk, 2004; Cervone, 2004), aspects of self-regulation processes (e.g., Banfield et al., 2004), developments of individual's capacity for self-regulation (Vohs \& Ciarocco, 2004), interpersonal components of self-regulation (Leary, 2004), and individual differences in selfregulation (Barkley, 2004). In applied settings, consequences of self-regulation have been studied quite extensively in areas such as addictive behaviour (Bechara, 2006; Sayette, 2006; Hull \& Slone, 2006) and consumer behaviour (Faber \& Vohs, 2004). Albeit such diversities, there are two basic properties shared by all theories of self-regulation (Cameron \& Leventhal, 2003). The first concerns the construal of self-regulation as a dynamic motivational system of setting goals, developing and enacting strategies to achieve those goals, appraising progress, and revising goals and strategies accordingly. The other property relates to the management of emotional responses as crucial elements of the motivational system.

The cybernetic control theory (Carver \& Scheier, 1981; Scheier \& Carver, 1988; Carver, 2004) provides a succinct explanation of the dynamic motivational setting. The theory views individuals' behaviours as a continuous process of movement toward (and sometimes away from) goals. The self-regulatory mechanisms ensure that feedback loops are present in the continuous movement. A feedback loop consists of four components, namely input function, reference value (goals, standards), comparator, and output function (Carver, 2004). The process is analogous to the mechanism of a thermostat: sensors detect the temperature of the room (input function), the comparator compares the measured temperature with the predetermined (goals, standard) desired temperature, the heating or cooling mechanism is activated (output function). Figure 1. summarises the theory in the context of generic level of consumer behaviour.

It is obvious that goals are primary components of self-regulatory mechanisms. Fisbach, Dhar and Zhang (2006) state that setting goals and monitoring progress towards goal achievement are fundamental to theories of self-regulation. Goals concerns any type of desired states that individuals possess, such as personal striving (Emmons, 1989), possible selves (Markus \& Nurius, 1986), and self-guide (Higgins, 1996). Goals can be understood from its conceptual construction, i.e., structural properties, goal processes, and goal contents (Austin \& Vancouver, 1996; Pervin, 1989; Kruglanski et al., 2002). The functions of goals are to energize and direct behaviour (Kruglanski et al., 2002). Besides, in the self-regulation mechanisms, goals serve as reference values in feedback loops.

Toward this end, a self-regulation approach requires a generic goal system as a property of the consumer decision making at the generic allocation level. Built on the goal system theory (Kruglanski et al., 2002), a generic goal system consists of desired states that are relevant, and associative networks between goals. The associative networks between goals explain the hierarchical structure of goal systems (Kruglanski et al., 2002), and the means-end framework of goal-pursuit behaviour (K.G. Grunert \& 


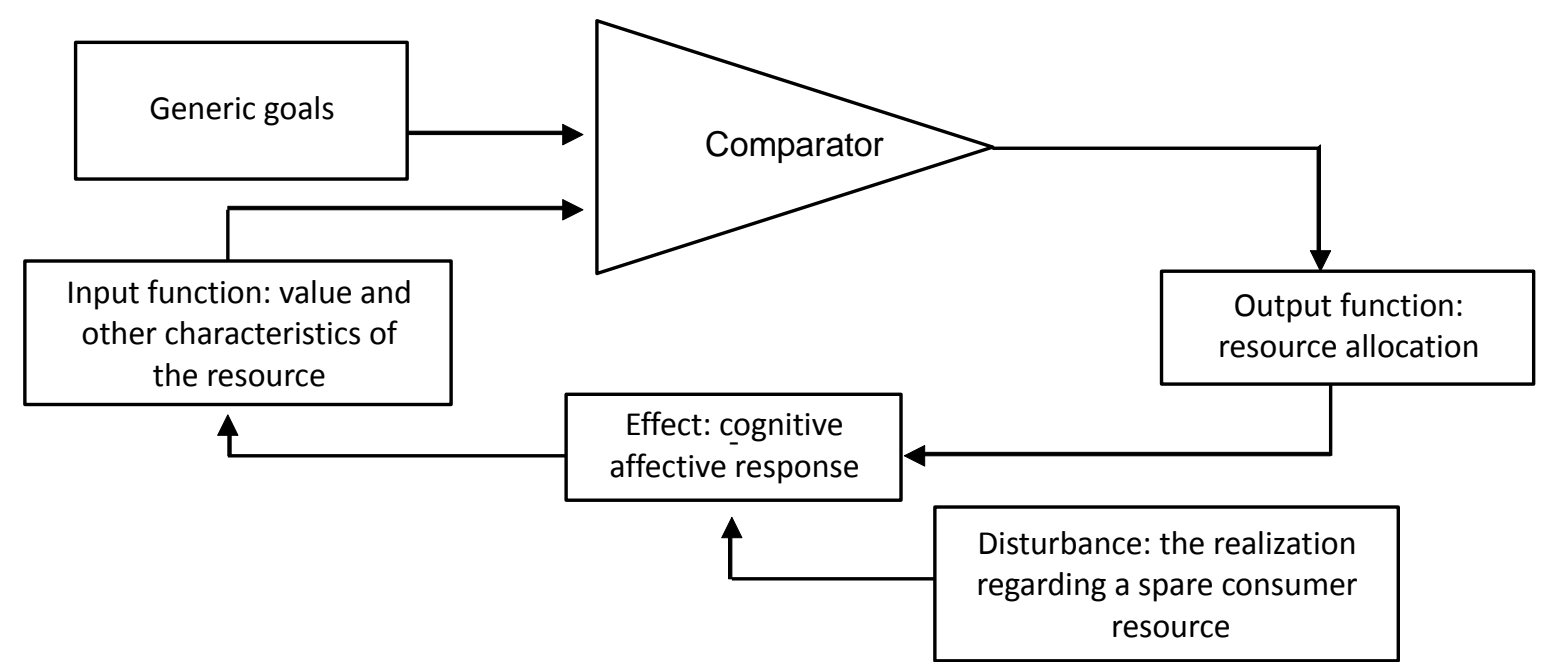

Figure 1. Schematic depiction of a feedback loop of a cybernetic control in a generic allocation situation of consumer behavior (adapted from Carver, 2004, p. 14).

S.C. Grunert, 1995). Based on Austin and Vancouver (1996), and Bagozzi, Bergami and Leone (2003), generic goals are inherent in the self-regulatory mechanisms of the consumer, and simply lying dormant until they are made salient by relevant stimuli. The self-regulatory mechanism in the context of generic decision making regarding a windfall income can be explained as follows. The presence of windfall income enlightens the consumer on opportunities of achieving goals. The selfregulation processes starts with the comparison between the characteristics of the windfall income, i.e., the size and the source (Henderson \& Peterson, 1992), and the state of goals that become active. Decisions regarding allocations of the money into generic-level budgets, i.e., spending and saving, follow from the comparison processes. The mental accounting processes of the decision making (Thaler, $1980,1985,1999)$ implies that there are differences in the marginal propensity to consume the same amount of incomes but of different characteristics of sources. Thus a self-regulation approach predicts different behaviours of a windfall income as compared to the economic approach, and different explanations of the same types of behaviour as compared to the behavioural approach. In addition, the self-regulatory approach focuses on the explanation of processes, whereas the economic and behavioural approaches focus on the outcome of behaviour. Generic goal systems constitute one of the psychological constructs in the self-regulation of consumer behaviour at the generic level.

\section{Way forward}

Our review so far favours the social cognitive approach to consumer behaviour at the generic level. Further, the preceding section concludes with a hypothetical generic goal system as a necessary psychological construct in consumer behaviours at this level. This hypothesis reflects a topdown view, i.e., consumer behaviours that are goal-driven (e.g., Paulssen \& Bagozzi, 2005; Park \& Smith, 1989; Bettman, Luce, \& Payne, 1998), in contrast to the bottom-up view, i.e., consumer behaviours that are product-driven (e.g.Johnson, 1984, 1988). To the best of our knowledge, there is no effort yet at examining what goals constitute a generic goal system, how these goals are organized, and how generic goal 
systems explain differences in consumer behaviour at the generic level. Therefore this section attempts to higlight way forwards in consumer behaviour research with a focus on eliciting, constructing, and applying the generic goal systems in the explanation of consumer decision making. The specific research questions can be described as follow.

What is the appropriate method and procedure for eliciting generic goals and its organizational properties?

As discussed above, a generic goal system comprises multiple goal contents that are organized in certain ways. In addition, there might be individual differences in the generic goal systems. Differences between individuals may be characterized in terms of different contents of the generic goal system, or it might be in terms of different organization of the same goal contents, or a combination of content and organization of the generic goal system. Following on this rationale, a focus on eliciting the subject's goals and how these goals are interrelated are more appropriate for the purposes of this study, rather than focusing on measuring how strongly the subjects are committed to certain goals. Whereas goal elicitation implies an idiographic approach, which is more suitable for taping into a subjective construct, such as consumer goal systems, measurements using psychological scales are more appropriate for testing a hypothesis concerning a predetermined psychological construct (Gravetter \& Forzano, 2006).

Among the goal elicitation methods, the laddering technique has gained wide acceptance as a method that satisfies such a requirement. Other methods include projective techniques (McClelland, 1961; Malhotra \& Peterson, 2006). Several varia- tions in the laddering technique have been developed, such as the laddering technique for eliciting the means-end chain of consumer consumption (Reynolds \& Gutman, 1988), for eliciting superordinate goals (Pieters, Baumgartner, \& Allen, 1995; Bagozzi, Bergami, \& Leone, 2003), and for eliciting personal values in organizational contexts (Bourne \& Jenkins, 2005). However, these methods were designed for eliciting consumer goal systems at more specific levels. For example, the means-end chain model is concerned with goals in the context of choice between brands in a product category. On the other hand, the superordinate goal laddering procedure is concerned with specific focal goals that may signify choices between modal behaviours. A generic allocational context involves categories of consumer behaviour such as spending, saving, investing, and repaying debt. Empirical work on this area of study should attempts to answer is what specific aspects of the laddering procedure are required for eliciting generic goals and its organizational properties.

What are the generic goals and how are they organized?

By definition, a generic goal system includes all goals that become salient in a generic level of consumer decision making. This may include goals as broad as maximizing utility as assumed in economic theories. More specifically, goals of enjoying stable levels of consumption, as postulated in the life-cycle (Modigliani \& Brumberg, 1954) and the permanent income theories (Friedman, 1957), are likely to be part of the generic goal systems. In addition, included in the generic goal systems are specific motives such as keeping with referent persons in terms of possessions and lifestyle, a phenomenon which is often addressed as the tendency 
to keep up with the Jones's (Duesenberry, 1949; Schor, 2000). Different types of saving motives such as explained in Keynes (1936/1964), Browning and Lusardi (1996), and Katona (1975) also appear to fit in the generic goal system. Goals at the generic level may represent what consumers express as needs, wants, desires, motives, and values (e.g., Belk, Ger, \& Askegaard, 2000; Rokeach, 1973; Schiffman \& Kanuk, 2004; Maslow, 1954), especially with regard to consumption motives. The problem studies on this area should attempt to address is, among others, how these goals are organized in the generic goal systems.

Research demonstrates that individuals have to spend higher efforts when multiple goals are salient at the same time (Bettman, Luce, \& Payne, 1998). The relationships between the salient goals can be characterized in terms of either substitutive, complementary, or competing (Kruglanski et al., 2002). Higher cognitivemotivational processing is required when multiple goals are incompatible to each other (Jain \& Maheswaran, 2000). In this regard, saving and spending goals are naturally competing (Katona, 1975), since what is saved cannot be spent, and vice versa. Because the generic level of consumer behaviour involves spending and saving goals (Van Veldhoven \& Groenland, 1993; Antonides \& Van Raaij, 1998), and because goal organization facilitates individual functioning in the context of the salience of multiple goals (Kruglanski et al., 2002), this study assumes that goals at the generic level are structured in certain fashion. The problem that we should be focused on is how generic consumer goals are organized, what are the organizational properties, and to which degrees are generic goals independent and interdependent of each other.
What factors determine the formation of generic goal systems?

Evidence of individual differences in consumer behaviour is paramount. Almost every handbook in consumer behaviour, e.g., Antonides and Van Raaij (1998), Assael (1992), Schiffman and Kanuk (2004), spent a chapter on the topic of individual differences. In the financial domain, Wärneryd (1999) describe consumers of the same income levels, life-cycle stages, and demographic backgrounds as often different to each other with regards to their wealth and financial preparedness in retirement. Wealth and pensions are the direct results of retirement planning (Selnow, 2004), which involves decision makings at the generic level. Given that consumer decision making is goal-driven (Van Oesselaer, 2006), we should expect that individual differences in the wealth and pension levels are influenced by differences in the generic goal systems. The question any research in this areas should like to answer is what are the psychological and demographic factors that determine differences in the generic goal systems of individuals.

\section{References}

Antonides, G., \& Van Raaij, W. F. (1998). Consumer behaviour: A European perspective. Chichester, UK: John Wiley \& Sons.

Assael, H. (1992). Consumer behavior and marketing action (4th ed.). Boston: PWSKent.

Austin, J. T., \& Vancouver, J. B. (1996). Goal constructs in psychology: Structure, process, and content. Psychological Bulletin, 120, 338-375.

Bagozzi, R. P., Bergami, M., \& Leone, L. (2003). Hierarchical representation of 
motives in goal setting. Journal of Applied Psychology, 88, 915-943.

Bandura, A. (1986). Social foundations of thought and action: A social cognitive theory. Englewood Cliffs, NJ: PrenticeHall.

Bandura, A. (2001). Social cognitive theory: An agentic perspective. Annual Review of Psychology, 521-526.

Banfield, J. F., Wyland, C. L., Macrae, C. N., Münte, T. F., \& Heatherton, T. F. (2004). The cognitive neuroscience of self-regulation. In R.F. Baumeister \& K.D. Vohs (Eds.), Handbook of selfregulation: Research, theory, and applications (pp. 62-83). New York: Guildford Press.

Barberis, N., \& Thaler, R. (2003). A survey of behavioral finance. In G.M. Constantinides, M. Harris, \& R. Stulz (Eds.), Handbook of the economics of finance (pp. 1051-1121). Amsterdam: Elsevier.

Barkley, R. A. (2004). Attention-deficit/hyperactivity disorder and selfregulation. In R.F. Baumeister \& K.D. Vohs (Eds.), Handbook of self-regulation: Research, theory, and applications (pp. 301-323). New York: Guildford Press.

Baron, J. (2000). Thinking and deciding. Cambridge, UK: Cambridge University Press.

Baumeister, R. F., Heatherton, R. F., \& Tice, D. M. (1994). Losing control: How and why people fail at self-regulation. San Diego: Academic Press.

Bechara, A. (2006). Broken willpower: Impaired mechanisms of decision making and impulse control in substance abuse. In N. Sebanz \& W. Prinz (Eds.), Disorders of volition (pp. 399418). London: Bradford Books.
Belk, R. W., Ger, G., \& Askegaard, S. (2000). The missing streetcar named desire. In S. Ratneshwar, D.G. Mick, \& C. Huffman (Eds.), The why of consumption: Contemporary perspectives on consumer motives, goals, and desires (pp. 98119). London: Routledge.

Bettman, J. R., Luce, M. F., \& Payne, J. W. (1998). Constructive consumer choice processes. Journal of Consumer Research, 25, 187-217.

Bourne, H., \& Jenkins, M. (2005). Eliciting managers' personal values: An adaptation of the laddering interview method. Organizational Research Methods, $8,410-428$

Browning, M., \& Lusardi, A. (1996). Household saving: Micro theories and micro facts. Journal of Economic Literature, 34, 1797-1855.

Cameron, L. D., \& Leventhal, H. (2003). Self-regulation, health and illness: An overview. In L.D. Cameron \& H. Leventhal (Eds.), The self-regulation of health and illness behaviour (pp. 1-13). London: Routledge.

Caprara, G. V., \& Cervone, D. (2000). Personality: Determinants, Dynamics, and Potentials. Cambridge, UK: Cambridge University Press.

Carballo, M., Heal, B., \& Horbay, G. (2006). Impact of the tsunami on psychosocial health and well-being. International Review of Psychiatry, 18, 217-223.

Carver, C. S. (2003). Self-regulation. In A. Tesser \& N. Schwarz (Eds.), Backwell handbook of social psychology: Intraindividual processes (pp. 307-328). Oxford, UK: Blackwell Publishing

Carver, C. S. (2004). Self-regulation of action and affect. In R.F. Baumeister \& K.D. Vohs (Eds.), Handbook of selfregulation: Research, theory, and applica- 
tions (pp. 13-39). New York: The Guildford.

Carver, C. S., \& Scheier, M.F. (1981). Attention and Self-Regulation: A ControlTheory Approach to Human Behavior. New York: Springer-Verlag.

Cervone, D. (2004). The architecture of personality. Psychological Review, 111, 183-204.

Dhar, R., \& Wertenbroch, K. (2000). Consumer choice between hedonic and utilitarian goods. Journal of Marketing Research, 37, 60-71

Duesenberry, J. S. (1949). Income, saving, and the theory of consumer behavior. Cambridge, MA: Harvard University Press.

Earl, P. E. (1990). Economics and psychology: A survey. The Economic Journal, 100, $718-755$.

Emmons, R. A. (1986). Personal strivings: An approach to personality and subjective well-being. Journal of Personality and Social Psychology, 51, 1058-1068.

Faber, R. J., \& Vohs, K. D. (2004). To buy or not to buy? Self-control and self-regulatory failure in purchase behavior. In R.F. Baumeister \& K.D. Vohs (Eds), Handbook of self-regulation: Research, theory, and applications (pp. 509-524). New York: The Guildford.

Fisbach, A., Dhar, R., \& Zhang, Y. (2006). Sub-goals as substitutes or complements: The role of goal accessibility. Journal of Personality and Social Psychology, 91, 232-242.

Friedman, M. (1953). Choice, chance, and the personal distribution of income. The Journal of Political Economy, 61, 277290.

Friedman, M. (1957). A theory of the consumption function. Princeton: Princeton University Press.
Gardner, J., \& Oswald, A. (2001). Does money buy happiness? A longitudinal study using data on windfalls. Retrieved January 26, 2009, from http: //www. warwick.ac.uk/fac/soc/Economics/osw ald/marchwindfalls.GO.pdf.

Gravetter, F. J., \& Forzano, L-A. B. (2006). Research methods for the behavioral sciences $\left(2^{\text {nd }}\right.$ ed.). Belmont: CA: Wadsworth/Thomson Learning.

Grunert, K. G., \& Grunert, S.C. (1995). Measuring subjective meaning structures by the laddering method: Theoretical considerations and methodological problems. International Journal of Research in Marketing, 12, 209225.

Gustman, A .L, \& Juster, F. T. (1996). Income and wealth of older American households: Modeling issues for public policy analysis. In E.A. Hanushek \& N.L. Maritato (Eds.), Assessing knowledge of retirement behavior (pp. 11-60). Washington, D.C.: National Academy Press.

Henderson, P. W., \& Peterson, R. A. (1992). Mental accounting and categorization. Organizational Behaviour and Human Decision Processes, 51, 92-117.

Hetherington, E. M., \& Kelly, J. (2002). For better or for worse: Divorce reconsidered. New York: W.W. Norton \& Company.

Higgins, E. T. (1996). The "self-digest": Self-knowledge serving self-regulatory functions. Journal of Personality and Social Psychology, 71, 1062-1083.

Hogarth, R. M., \& Reder, M. W. (1986). Perspectives from economics and psychology. The Journal of Business, 59, S185-S207.

Huffman, C., Ratneshwar, S., \& Mick, D. J. (2000). Consumer goal structures and goal-determination processes. An integrative framework. In S. 
Ratneshwar, D.G., Mick, \& C. Huffman (Eds.), The why of consumption (pp. 9-35). London: Routledge.

Hull, J. G., \& Slone, L. B. (2006). A dynamic model of the will with an application to alcohol-intoxicated behavior. In N.Sebanz \& W. Prinz (Eds.), Disorders of Volition (pp.439-455). London: Bradford Book.

Jain, S. P., \& Maheswaran, D. (2000). Motivated reasoning: A depth-ofprocessing perspective. Journal of Consumer Research, 26, 358-371.

Johnson, M. D. (1984). Consumer choice strategies for comparing noncomparable alternatives. Journal of Consumer Research, 11, 741-753.

Johnson, M. D. (1988). Comparability and hierarchical processing in multialternative choice. Journal of Consumer Research, 15, 303-314.

Jolls, C., Sunstein, C. R., \& Thaler, R. (1998). A behavioral approach to law and economics. Stanford Law Review, 50, 1471-1550.

Kahneman, D., \& Tversky, A. (1984). Choices, values, and frames. American Psychologist, 39, 341 - 350.

Karoly, P. (1993). Mechanisms of selfregulation: A systems view. Annual Review of Psychology, 44, 23-52.

Katona, G. (1975). Psychological economics. New York: Elsevier.

Keynes, J. M. (1936/1964). The general theory of employment, interest, and money. San Diego: Harcourt.

Kirzner, I. M. (1997). Entrepreneurial discovery and the competitive market process: An Austrian Approach. Journal of Economic Literature, 35, 60-85.

Kruglanski, A. W., Shah, J.Y., Fishbach, A., Friedman, R., Chun, W.Y., \& SleethKeppler, D. (2002). A theory of goal systems. Advances in experimental social psychology, 34, 331-378.

Kunda, Z. (1999). Social cognition: Making sense of people. Cambridge, MA: MIT

Lea, S. E. G., Tarpy, R. M., \& Webley, P. (1987). The individual in the economy. Cambridge, UK: Cambridge University Press.

Leary, M. R. (2004). The function of selfesteem in terror management theory and sociometer theory: Comment on Pyszczynski et al. (2004). Psychological Bulletin, 130, 478-482.

Lopes, L. L. (1994). Psychology and economics: Perspectives on risk, cooperation, and the marketplace. Annual Review of Psychology, 44, 197-227.

Lunt, P. (1996). Rethinking the relationship between economics and psychology. Journal of Economic Psychology, 17, 275287.

Malhotra, N. K., \& Peterson, M. (2006). Basic marketing research: A decisionmaking approach. Upper Saddle River, NJ: Pearson Education.

Markus, H., \& Nurius, P. (1986). Possible selves. American Psychologist, 41, 954969.

Maslow, A. (1954). Motivation and personality. New York: Harper \& Row.

McClelland, D. C. (1961). The achieving society. Princeton, MA: Van Nostrand.

Miscel, W., \& Ayduk, O. (2004). Willpower in a cognitive-affective processing system. In R.F. Baumeister \& K. D. Vohs (Eds.), Handbook of self-regulation: Research, theory, and applications (pp. 99-129). New York: The Guildford.

Modigliani, F. (1986). Life cycle, individual thrift, and the wealth of nations. The American Economic Review, 76, 297-313. 
Modigliani, F., \& Brumberg, R. (1954). Utility analysis and the consumption function. An interpretation of crosssection data. In K.K. Kurihara (Ed.), Post-Keynesian economics (pp. 388-438). New Brunswick, NJ: Rutgers University Press.

Mullainathan, S., \& Thaler, R. H. (2000). Behavioral economics. National Bureau of Economic Research. Working Paper 7948. Retrieved November 17, 2001, from http://www.nber.org/ papers/w7948.

Nissle, S., \& Bschor, T. (2002). Winning the jackpot and depression: Money cannot buy happiness. International Journal of Psychiatry in Clinical Practice, 6, 183186.

Nyhus, E. K. (2002). Psychological determinants of household saving behavior. Unpublished doctoral dissertation, Norwegian School of Economics and Business Administration, Norway.

Park, C. W., \& Smith, D. C. (1989). Product-level choice: A top-down or bottom-up process? Journal of Consumer Research, 16, 289-299.

Paulssen, M, \& Bagozzi, R. P. (2005). A Self-regulatory model of consideration set formation. Psychology and Marketing, 22, 785-812.

Pervin, L. A. (Ed.). (1989). Goal concepts in Personality and Social Psychology. Hillsdale, NJ: Erlbaum.

Pieters, R., Baumgartner, H., \& Allen, D. (1995). A means-end chain approach to consumer goal structures. International Journal of Research in Marketing, 12, 227244.

Poortman, A-R. (2002). Socioeconomic causes and consequences of divorce. Unpublished doctoral dissertation, University of Utrecht, The Netherlands.
Poterba, J. M. (1996, July). Demographic structure and the political economy of public education. NBER Working Paper No.W5677. Retrieved February 2, from http://www.nber.org/papers/ w5677.

Reynolds, T. J., \& Gutman, J. (1988). Laddering theory, method, analysis and interpretation. Journal of Advertising Research, 28 (February/March), 11-31.

Rokeach, M. (1973). The Nature of Human Values. London: The Free Press.

Samuelson, P. A., \& Nordhaus, W.D. (1992). Economics (14 ${ }^{\text {th }}$ ed.). New York: McGraw-Hill.

Sayette, M. A. (2004). Craving, cognition, and the self-regulation of cigarette smoking. In N.Sebanz \& W. Prinz (Eds.), Disorders of volition (pp. 419437). London: Bradford Book.

Schiffman, L. G., \& Kanuk, L. L. (2004). Consumer behavior ( $8^{\text {th }}$ ed.). Upper Saddle River, NJ: Pearson.

Schor, J. B. (2000). Towards a new politics of consumption. In J.B. Schor \& D.B. Holt (Eds.), The consumer society (pp. 446-462). New York: New Press.

Selnow, G. W. (2004). Motivating retirement planning: Problems and solutions. In O.S. Mitchell \& S.P. Utkus (Eds.), Pension design and structure: New lessons from behavioral finance (pp. 43-51). New York: Oxford University Press.

Shefrin, H. M., \& Thaler, R. H. (1988). The behavioural life-cycle hypothesis. Economic Inquiry, 26, 609-643.

Thaler, R. H. (1980). Toward a positive theory of consumer choice. Journal of Economic Behavior and Organization, 1, 39-60. 
Thaler, R. H. (1985). Mental accounting and consumer choice. Marketing Science, 4, 199-214.

Thaler, R. H. (1994). Psychology and savings policies. The American Economic Review, 84, 186-192.

Thaler, R. H. (1999). Mental accounting matters. Journal of Behavioral Decision Making, 12, 183 - 206.

Thaler, R. H. (2000). From homo economicus to homo sapiens. Journal of Economic Perspectives, 14, $133-141$.

Thaler, R. H., \& Benartzi, S. (2004). Save More Tomorrow ${ }^{\mathrm{TM}}$ : Using behavioural economics to increase employee saving. Journal of Political Economi,112, S164-S187.

Thaler, R. H., \& Shefrin, H. M. (1981). An economic theory of self-control. Journal of Political Economy, 89, 392-406.

Terhell, L. (2003). Changes in the personal network after divorce. Unpublished doctoral dissertation, University of Tilburg, The Netherlands.

Tversky, A., \& Kahneman, D. (1981). The framing of decisions and the psychology of choice. Science, 211, 453-458.

Tversky, A., \& Kahneman, D. (1986). Rational choice and the framing decisions. Journal of Business, 59, 5251 5278.

Van Oesselaer, S. J., Ramanathan, S., Campbell, M. C., Cohen, J. B., Dale, J. K., Janiszewski, C., et al. (2005). Choice based on goals. Marketing Letters, 16, 335-346.
Van Raaij, W. F. (1999). Economic psychology between psychology and economics: An Introduction. Applied Psychology: An International Review, 48, 263-272.

Van Solinge, H. (2006). Changing tracks: Studies on life after early retirement in the Netherlands. Unpublished doctorate dissertation, The Netherlands Interdisciplinary Demographic Institute, The Hague.

Van Veldhoven, G. M., \& Groenland, E. A. G. (1993). Exploring saving behaviour: A framework and a research agenda. Journal of Economic Psychology, 14, 507522.

Veblen, T. (1899/2000). Conspicuous consumption. In J.B. Schor \& D.B. Holt (Eds.), The consumer society (pp. 187204). New York: New Press.

Vohs, K. D., \& Ciarocco, N. J. (2004). Interpersonal functioning requires selfregulation. In R.F. Baumeister \& K.D. Vohs (Eds.), Handbook of self-regulation: Research, theory, and applications (pp. 392-410). New York: Guildford Press.

Vohs, K. D., \& Baumeister, R. F. (2004). Understanding self-regulation: An introduction. In R.F. Baumeister \& K.D. Vohs (Eds), Handbook of selfregulation: Research, theory, and applications (pp. 1-9). New York: The Guildford.

Wärneryd, K. E. (1999). The psychology of saving: A study on economic psychology. Cheltenham, UK: Edward Elgar. 